\title{
EFFECTS OF RECRUITMENT AND SELECTION AND PERFORMANCE OF PRIVATE SECONDARY SCHOOLS IN NYERI COUNTY, KENYA
}

\author{
Nderitu Eunice Wangui ${ }^{1 i}$, \\ Makhamara Felistus ${ }^{2}$ \\ 'Student, \\ School of Humanities and Social Sciences, \\ Kenyatta University, \\ Kenya \\ ${ }^{2}$ Lecturer, Dr., \\ School of Business, \\ Kenyatta University, \\ Kenya
}

\begin{abstract}
:
Human resource management (HRM) practices entail policies, systems, and methods that govern workplace employees. They are the processes or functions applied to manage workers and direct them in an organization towards development. Some of the HRM practices include recruitment, screening, selection, development, training, and rewarding of staff. A number of studies to investigate the interaction between HRM practices and organizational performance have been conducted. Many of these studies have been done in the manufacturing or health sectors, with very few having been carried out in private secondary schools. This background is what has necessitated this study in order to investigate the effect of human resource management practices on the performance of private secondary schools in Nyeri County, in Kenya. The objectives of the study were to determine the effect of recruitment, staff development and reward practices on organizational productivity and performance. The study used four theories i.e. ResourceBased View, the Social Exchange Theories, McGregor's theory X and Y, and the Human Capital to support it. The study targeted a population of 440 subjects. This included principals and their deputies, departmental heads, and classroom teachers of the private secondary schools in Nyeri County. The study adopted descriptive research design. The study applied stratified random sampling technique to pick schools for the research. Interview schedule was used for collecting data from principals, while data from the teachers was obtained through the utilization of questionnaires. The reliability of instruments in this study was established through Cronbach's alpha, while they were validated through content, construct, and discussion with the supervisor. Descriptive
\end{abstract}

${ }^{i}$ Correspondence: email eunanderitu2010@gmail.com 
statistics were utilized in the analysis quantitative data with the aid of Statistical Package for Social Sciences (SPSS) Version 20 to generate them. Qualitative data was analysed by thematic analysis, content analysis and discussion. The findings of the study were presented in frequency distribution tables.

Keywords: recruitment and selection practices and organizational performance

\section{Introduction}

Human resource management (HRM) practices comprise policies, systems and methods that affect employee performance, behaviour and attitude (Noe et al, (2007). They are the processes or functions used to manage workers and direct them in an organization towards development. It also involves the efficiency and effectiveness utilization of manpower in a business entity.

Huselid (2006) observes that the subject of HRMP and their effects on the performance of an organizational has received much attention from researchers in the last two decades. The human resource policies define the philosophies and values of the organization regarding the treatment of workers and the action concerning matters involving the workers.

Although the human resources of an organization are contemplated as the most perilous assets of an organization, the number of organizations that can completely utilize their potential has been relatively small, Ahmed, (2003). A notion has emerged that matching packages of human resource management practices improve performance of an organizational (William, 2010). Lew (2009) asserts that organizational workers perform a significant function in the improvement of rankings in important areas like the quality of the product, organizational status and the maintenance of relations with the general society. HRM practices are connected to the overall institutional performance and its employee's commitment. Previous studies discovered that intense involvement in human resource management practices like regular employee appraisals, compensation schemes, provision of training and development, and regular feedback can significantly enhance organizational performance and employee commitment (Meyer \& Smith, 2004). Accordingly, employees who are not satisfied by their work environment may cause challenges to an organization (Syed et al., 2012).

Several studies have demonstrated that HRM practices depend on how well the workforce policies and programs fit with the cultural background of the environment in which the methods are implemented (Debrah, et al., 2000). In effect, organizations need to establish strategies in human resource policies like recruitment and selection, training and development that reflect their beliefs and principles.

Organizational performance refers to the total progression of an organization (Drucker, 2002). It invariably implies the performance of an organization based on an increase in sale, finances and the employee's general development, Balpo (2016). Performance is also described as the accomplishment of a specific chore related to certain 
requirements of correctness, speed, cost and completeness that clears the concerned person from fulfilling all the liabilities of the contract. Daft (2000), conversely, views the performance of an organization as the capacity of an organization to accomplish its goals and objectives effectively and efficiently manner with the available resources. Ricardo et al., (2001) tend to agree with this definition, defining institutional performance as the accomplishment of the objectives, goal, and strategies that an organization has set for itself.

Richard et al. (2009) conducted a study on organizational performance which embodied three precise parts: shareholder return, financial performance and market performance. Shareholder return can be seen in terms of total returns to shareholders, economic value-added and such related variables. Market performance of an organization can be viewed with reference to sales, market and so on. The organizational output heavily relies on the human resource of the company. As such, for organizations to perform efficiently there is a need for a proficient and effective management of their human resources. Ahmad, (2003) advises that it is essential to give considerable attention to human resources so that the workers can put up their full potential.

The human resource in an organization refers to the individual workers or staff within the organization's boundary. The team is in charge executing the duties allocated to them to achieve organizational objectives and creating income for the organization. Therefore, the workers are a valuable asset in any organization as the workers capacities determine the success or failure of an organization (Rehman, 2011). Besides, human resource management practices should be such that they enhance workers' personal development to perform their duties with diligence.

Private secondary schools are run and managed by private individuals. Such institutions may be built-in private lands owned by the proprietors, or hired lands paid for at agreed rates. Private secondary schools are usually run as businesses, generally making a profit to the owners. The general organization of private secondary schools varies from one school to the next still, in most cases, they are characterized by lean staff that can just perform the duties for which the schools are established. Workers in such schools are paid lower salaries than equivalent workers in public schools since their salary comes directly from the learners' fee.

\section{Statement of the Problem}

The management of human resources is a critical area in any organization. It becomes an even bigger issue for private secondary schools since the personnel in schools keep comparing their treatment to how staff performing similar duties in public schools is treated. They examine their therapy in nearly all facets of human resource management practices, including recruitment and selection (Boxall and Prucell, 2016).

While human resources in public schools are employed on a permanent and pensionable basis, most academic staff in private schools are employed on contract basis. They hence do not earn as much as their counterparts in the public sector. This is almost 
a uniform situation in most private secondary schools (Byd, Lankford, Loed, Ronfeldt \&Wyckoff, 2011).

A number of researches have been conducted on the effects of HRM practices on employee productivity. One such study by Makhamara (2017) on impact of strategic HRM policies on the productivity of workforces in Level-5 public healthcare facilities in Kenya found that although the hospitals had recruitment and selection policies, the policies were not being enforced, a situation that resulted in high employee turnover. The study also established that there were employee training policies in the public hospitals, but the policies were not enforced, and this affected performance. But staff development policies were completely lacking. Another study by Nyandiko and Ongeri (2015), established that in many cases, organizational gives attention to the execution of HRM which result to organizational performance. This prevents the leaders from making long term projections for long term performance, and therefore poses a challenge in the implementation of human resource management objectives, with the net result that employee performance is negatively affected.

Munjuri (2011) conducted a study on the influences of HRM practices in promoting workforce productivity in catholic schools of higher learning in Kenya. The study discovered that performance-related compensation had the most significant influence on increasing production. However, no investigation was conducted on HRM practices in the private secondary learning institutions in Nyeri County. On the basis of this background, the research intends to explore the significance of workforce practices and productivity of private secondary schools in the County of Nyeri.

\subsection{Specific Objectives}

- To establish the effect of recruitment and selection on performance of private secondary schools in Nyeri County.

\section{Theoretical Review}

\subsection{Resource-Based View}

The RBV (resource-based view) is a management structure applied to establish the strategic assets and funds that an organization can use to attain a continuous competitive edge (Barney, 1991). The emergence of this theory is closely associated with a 1991 article by Barney, titled "Firm Resources and Sustained Competitive Advantage" (Barney, 1991). The theory suggests that organizations are diverse as they have various resources, implying that they can have different strategies due to the unusual mix of resources. The approach concentrates on the organizational managers' attention to the organization's internal resources to discover the resources, capacities, and proficiency with the probability of attaining a higher sustainable advantage.

A resource-based view refers to multidiscipline method that symbolizes a considerable change in the line of thinking (Fahy and Smithee, 1999). It is interdisciplinary because its development involved the subjects of economics, 
management, ethics, general business, law, and supply chain management (Hunt, 2013). The resource-based view theory emphasizes on the resources of an enterprise as necessary for organizing procedures and attaining a competitive advantage. In effect, Barney (1991) asserted that for assets to possess capacity as a means of competitive edge, the support need to be imperfectly imitable, rare, valuable, and not replaceable. Thus, organizations need to develop exclusive competencies that enhance their better performance than opponents by carrying out their processes in different ways from their competitors.

In respect a current research, the resource-based analysis theory was applied to gauge the application of human resource management practices in unique ways such that the organizations perform better than their peers in whatever business it is involved in. Specifically, in the case of private secondary schools, they are expected to apply the theory to use the resources owned by the schools to offer better educational structures as well as better instructional methods leading to better learning processes in general. This theory supports the selection and recruitment variable in the study of HR management practice and private high secondary schools based in Nyeri County perform.

\subsection{Social Exchange Theory}

The social exchange theory supposes that motivational tasks performed between the workers and the organization gives rise to organizational commitment of the workers (Aldhuwaihi, 2013). Based on this theory, workers join an organization while expecting that the organization would provide a good working environment as well as a good culture. The workers therefore try the best means and methods of using their knowledge and skills to achieve organizational objectives. In effect, the positive relationship between the organization and its workers give rise to improved worker commitment to the organization. The social exchange theory postulates that a causal relationship is formed between the worker and the organization, which ensures an exchange between organizational culture and organizational commitment that positively affects organizational performance.

Social exchange theory is based on three philosophies, namely reciprocity, rationality and specificity to expound the correlation between the workers and their employer (Foa \& Foa, 2012). The reciprocity principle assumes that the social interaction between the workers and the organization is usually reciprocal in nature such that the worker gains from the organization's positive outlook while the organization gains from the employees' satisfaction. The rationality principle assumes that the workers usually exhibit a positive relationship with an organization that provides positive returns that can satisfy the wants and needs of the workers. Specificity principle, on the other hand, mutual benefit type of relationship can endure a kind of switch over rapport between the workers and the company. In effect, the employees consider that a good culture within an organization and strategic orientation would focus the organization towards the right activities that increase the workers' commitment to their organization (Pinho et al., 2014). According to Kidombo and his colleagues (2012), in such mutual exchange, the 
commitment of the employee may manifest itself in the form of a desirable feeling of loyalty to the organization. This greatly affects the outcomes of an organization, one major outcome being employee performance. It therefore follows that the association between culture, performance, commitment and organizational strategic orientation of the organization are interconnected and portrays a relationship based on resource exchange.

\subsection{Empirical Literature Review}

The method of recruitment entails sourcing, advertising, interviewing and selecting future workers in an organization. According to Armstrong (2010), the recruitment process involves conscription and training of new workers in their roles in the new work. Staff recruitment and selection lie at the centre of human resources management's perception of sustaining competitive advantage over business rivals (Sangeetha, 2010). The method of recruitment entails sourcing, advertising, interviewing, and selecting future workers in an organization. According to Branine (2008), for a business entity to attain and maintain a competitive advantage over its rivals, it should treat each step in the recruitment and selection very carefully. The effect of the decisions made during these processes will have long-term effects on the organization, with high economic effects, especially if the process had some pitfalls (Henderson, 2011).

Armstrong (2014) indicates that organizations should adopt universal HR management which is tailored to provide the basis of achieving better results from the organizational workers. Some of the steps required in planning for recruitment include analysis of recruitment strengths, weaknesses, candidate requirements, and identification of candidates' sources. Branine (2008) explains that an active recruitment program appeals to many potential applicants. When the number of applicants is large, the employing organization has an enormous pool of potential employees from where to pick the best among them.

A study by Makhamara (2016) on the influence of strategic selection and recruitment on employee output in Kenya's health industry, a total of 1428 workers employed on permanent terms in four public county hospitals in Kenya were targeted. The studied hospitals were county hospitals in the counties of Kakamega, Kajiado, Bungoma, and Kangund. Respondents included Senior Administration staff consisting of the hospital administrator, Middle Administration staff, lower administration staff, and ordinary workers. 146 being the chosen sample employing simple and stratified random sampling techniques, the leading purpose for the study was to identify the repercussion of strategic selection and recruitment process on the productivity of workers in the Kenyan Health Segment. Hypothesis for the research was that that strategic selection and recruitment of staffs contribute to a substantial favourable outcome on the workers' productivity in Kenya's health segment. The research used a cross-sectional study design survey. The design employed both quantitative and qualitative research approaches. Interview schedules and questionnaires were utilized to collect relevant data for the research. The research established that all hospitals studied 
had recruitment and selection policies used during staff recruitment and selection, which drastically reduced employee turnover from over $77 \%$ before implementing the policy to less than $20 \%$ after implementing the policies. The study concluded that justice and clearness were not applied during the conscription and choice of employees in hospitals. Likewise, the internal promotion was not considered where experienced staff would be promoted to the next grade when a vacancy arose. The study also confirmed there were never any employment tests such as skill tests, aptitude, or intellectual / perceptive tests at the studied hospitals. Although the studied hospitals had policies on conscription and assortment, the policies were never applied, a situation that translated to the high turnover of talented and experienced workers. The study concluded that strategic hiring process predisposed the productivity of workers in the Kenyan health segment. Therefore, it is recommended that organizations adopt internal promotion, especially for qualified employees, to enhance and inspire employee morale.

Sabwami (2014) conducted a study on organizational performance and highperformance work practices based on Kenyan organizations. The study hypothesized that there would be a direct association between selective hiring and the performance of an organization, and that the participation of a worker has a substantial positive association with organizational performance. The research employed cross-sectional and descriptive survey design, which targeted 5866 workers from 3 organizations registered in the Nairobi stock exchange. From the target population, 361 respondents selected via a blend of simple random and stratified random sampling methods. The organizations studied were Kengen, Kenya Power Mumias Sugar Company. The only instrument of data collection to be used is questionnaires where 361 of them were issued, but 291 were returned, thus a questionnaire return rate of over $80 \%$. The study found that highperformance work customs like employee participation, job security, and selective hiring influence organizational performance. This is achieved by providing workers with the knowledge, competency, and aptitudes requisite to perform the responsibilities and the opportunity and motivation to perform them. Secondly, excellent performance work practices enhance the social structure in organizations, which eases interaction and collaboration among workers. The study revealed that these two procedures enhance job satisfaction, thereby assisting employees to be more productive and arrive at a better judgment. In effect, this lowers employee turnover and increase organizational performance compared to competitors. The study concluded that the embracing of highperformance practices by State Corporation affects an organization's performance. Thus, employee participation, job security, selective hiring, and involvement positively influence the performance of an organization.

Anyango et al. (2018) carried out an exploration on the effects of selection and recruitment standard on the performance of an institution at Kisii University in Kenya. Its study's principal objective was to identify aspects which adversely affect the productive the recruitment and selection processes. The main research question that guided the study was based on the staff's perceptions of the selection and recruitment processes of their institution. Case study design approach was applied in the study, 
which targeted 226 teaching staff and seven members of management. Using the Slovin's formula for sample size determination, the study ended up with a sample of 144 teaching staff with all the seven members of management included. Teaching staff was selected using stratified random sampling, which was selected from different schools and faculties. Data was obtained via the utilization of questionnaires subjected to the teaching staff, while scheduled interviews were employed to gather data from members of management. Quantitative analysis technique and qualitative approach were employed in the evaluation of data. The data was presented using figures, graphs, tables, and narrative descriptions. The research stated that employee recruitment and employee performance in the organization have a positive relationship. The recruitment of the right personnel enhances workers' performance and hence the organizational performance as a whole. However, the study pointed that the organization's recruitment and selection process was not all that fair.

\subsection{Conceptual Framework}

It is conceptualized that several variables unite to effects of an organizational performance. Some of the variables encompass recruitment and selection practices, and organizational performance. The interrelationship among these variables is portrayed in the figure below:

\section{Independent}

\begin{tabular}{l} 
Recruitment and selection practices \\
- Outsourcing \\
- Absorption of interns \\
\hline
\end{tabular}

Variable Dependent variable

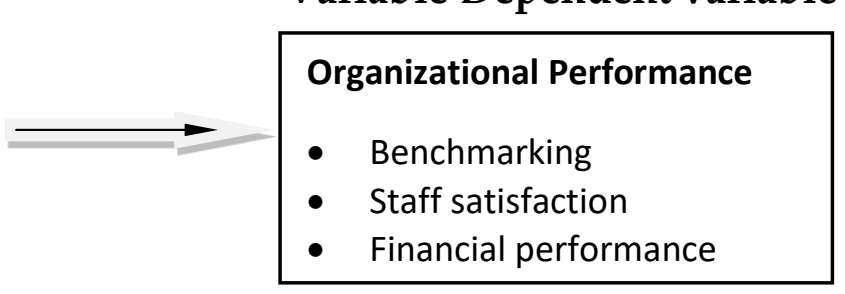

\section{Design of the Research}

The study adopted descriptive investigation survey design. Sekaran and Bougie (2011) asserts that a descriptive study design is utilized to describe subjects' behaviour concerning a given phenomenon. The model is applied to establish and enable an explanation of the features of the variable being considered. Since the research aims at addressing the effects of HRM practices and productivity of private secondary learning institutions, the research design is regarded as the most suitable for this kind of study

\subsection{Targeted Population}

This is the totality of group of things or persons that the study wishes to consider (Berenson \& Levine, 2014). The target population's importance is to set a strong course of action on the scope and objective of the study and data types. The target population of the study were the teachers working in twenty (20) Private secondary learning institutions in the County of Nyeri. The population size therefore comprised of 20 
principals, 20 deputy principals, 100 heads of departments and up to 300 classroom teachers making a total population of 440 respondents. The population size is as depicted in Table 3.1 that follows.

\subsection{Sampling Procedures and Sample Size}

The private secondary schools studied were spread in all the sub counties that make up Nyeri county. Nyeri County has a total of six sub counties namely Tetu, Kieni, Othaya, Mukurweini and Nyeri Township Sub County. Sampling process started from sampling of private secondary schools within the county. To start with, one private secondary school was purposively selected from each of the six sub counties. Proximity of the school in terms of accessibility and road network was used as the only variable for consideration here. In effect, six private secondary schools, one from each sub county, were included in the study.

From each of the six schools selected, the principal, deputy principal and the five heads of departments were included in the sample by virtue of the positions they hold. Census sampling method was then applied to selection of all the teachers in each of the six schools selected. In effect, the tabulated sample is as indicated below:

Table 3.2: Sampling Procedures and Sample Size

\begin{tabular}{|l|c|c|c|}
\hline Category & Target Population & Sample size & Percentage (30\%) \\
\hline Principals & 20 & 6 & $30 \%$ \\
\hline Deputy Principals & 20 & 6 & $30 \%$ \\
\hline Heads of Department & 100 & 36 & $36 \%$ \\
\hline Teachers & 300 & 90 & $30 \%$ \\
\hline Total & $\mathbf{4 4 0}$ & $\mathbf{1 3 8}$ & $\mathbf{3 4 . 5 \%}$ \\
\hline Source: Author 2020 & \\
\hline
\end{tabular}

From Table 3, it is clear that the study sample size comprised a total of 138 respondents.

\subsection{Data Collection Instruments}

Two different sets of tools were developed and utilized in data collection. These were a questionnaire for teachers and an interview schedule for head teachers. The questionnaires were semi-structured and contained questions comprising of open-ended and closed-ended nature. The questionnaires were piloted for their clarity to the respondents.

In order to collect data, a research permit was sought by the researcher from the relevant authorities. The first step was to seek an introductory letter for the researchers in Kenyatta University. With the introductory letter, the investigator had to make an application for research permit from NACOSTI. With the research permit, the investigator proceeded to Nyeri County Education office for additional permission at the local level. The research permit helped access the selected private secondary schools chosen for sampling. The researcher liaised with the respective principals from the targeted private secondary schools on the logistics specific day and time. This process 
proceeded hand in hand with collecting the filled-in questionnaires earlier issued to the various private secondary schools' teachers.

\subsection{Analysis and Presentation of Data}

This research is supposed to generate both qualitative and quantitative data. Qualitative data is usually verbal expressions recorded in the form of sentences rather than in quantifiable values, while quantitative information is generally in numerical values that express the size of items within the study. Collected data of both types were coded in themes and then the software SPSS version 20 was employed. Descriptive statistics were utilized in analysing quantitative data, which involved the determination of the mean, median, mode, and percentage where applicable. The SPSS program version 20 was used to assist in this process. Triangulation, content, and thematic analysis and discussion were used to analyse qualitative data (Orodho, 2017).

\section{Data Analysis, Presentation and Interpretation}

A total sample of 138 was used for the study based. As such, questionnaires were issued to a total of 138 respondents. However, on a collection of the questionnaires, a total of 112 completely filled-in questionnaires were collected. This resulted to the following response rate:

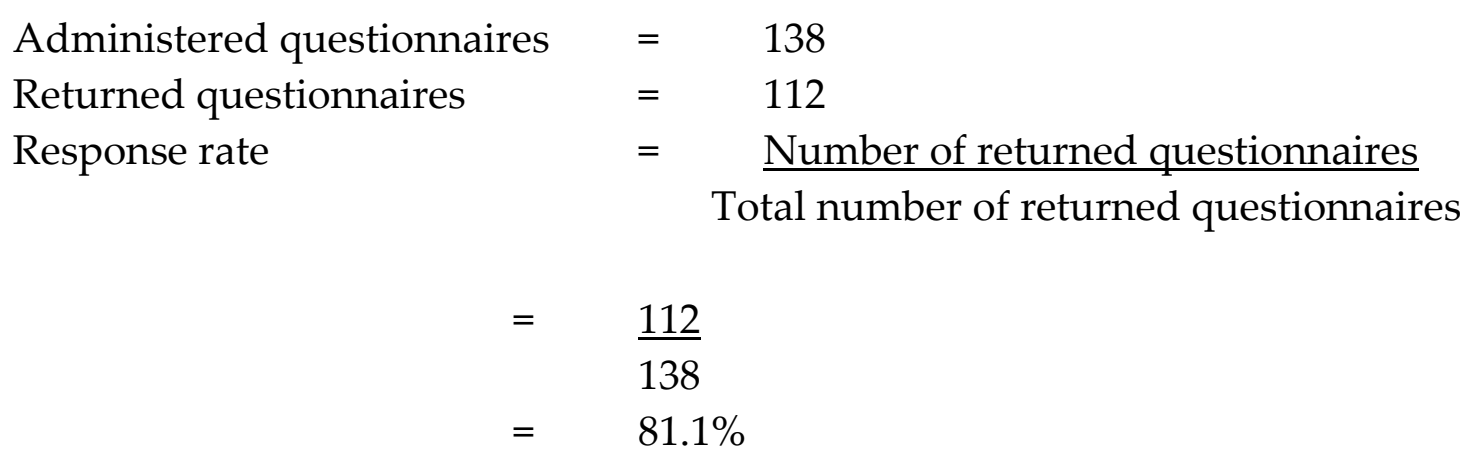

Thus, the response rate for the entire study was $81.1 \%$. This rate of response was considered fair enough given that an overwhelming majority of the sample effectively responded to the study.

\subsection{Effect of Recruitment and Selection on Performance of Private Secondary Schools} The first research question was: What is the effect of recruitment and selection on the performance of private secondary schools in Nyeri County? To answer this question, a series of statements were presented to the respondents. The respondents were required to tick from the table to what level they agree on the effect of recruitment and selection. The table that follows shows the outcome from the participants. 
Table 4.5: Effect of Recruitment and Selection on Performance Student Performance

\begin{tabular}{|c|c|c|c|c|c|c|}
\hline \multirow[t]{2}{*}{ S/no } & \multirow[t]{2}{*}{ Statement } & \multicolumn{5}{|c|}{$\begin{array}{l}\text { Frequency for each } \\
\text { of the preferred choices }\end{array}$} \\
\hline & & 1 & 2 & 3 & 4 & 5 \\
\hline 1 & $\begin{array}{l}\text { My organization carries out recruitment and selection } \\
\text { while employing new teachers }\end{array}$ & 1 & 0 & 3 & 19 & 89 \\
\hline 2 & $\begin{array}{l}\text { Poaching is one of the recruitments and selection } \\
\text { methods of employment }\end{array}$ & 47 & 45 & 12 & 6 & 2 \\
\hline 3 & $\begin{array}{l}\text { Fair recruitment and selection process enhance better } \\
\text { performance on the job }\end{array}$ & 1 & 0 & 1 & 10 & 100 \\
\hline 4 & $\begin{array}{l}\text { The school uses methods of advertising such as gazette, } \\
\text { internet channels while recruiting }\end{array}$ & 0 & 1 & 0 & 34 & 77 \\
\hline 5 & $\begin{array}{l}\text { Employees recruited through absorption from } \\
\text { internship/poaching adapt well to the school } \\
\text { environment }\end{array}$ & 0 & 1 & 8 & 11 & 92 \\
\hline
\end{tabular}

Note: Scale ( $1=$ strongly disagree, $2=$ disagree, $3=$ undecided, $4=$ agree, $5=$ strongly agree)

\subsection{Conduction of Recruitment and Selection}

Table 4.5 indicates that most of the participants felt that the school in which they work conducted recruitment and selection when employing new teachers. The following Table 4.6 portrays the situation regarding this investigation.

Table 4.6: Conduction of Recruitment and Selection for New Employees

\begin{tabular}{|l|c|c|}
\hline Statement & Frequency & Percentage (n =112) \\
\hline Strongly disagree & 1 & 1 \\
\hline Disagree & 0 & 0 \\
\hline Undecided & 3 & 3 \\
\hline Agree & 19 & 17 \\
\hline Strongly agree & 89 & 79 \\
\hline
\end{tabular}

In Table 4.6, the data indicate that a significant number of the participants maintained the view that their schools conducted recruitment and selection as a means of employing new teachers. This position was supported by $79 \%$ who strongly agreed with the statement and a further $17 \%$ who agreed. This brings $96 \%$ of the participants who agreed with this perception. However, $3 \%$ of respondents were not sure of the situation and therefore remained undecided while only $1 \%$ strongly disagreed. Therefore, it can be determined that secondary schools studied conducted recruitment and selection as a means of employing new teachers rather than just picking them through any other method.

\subsection{Poaching as a Method of Employee Recruitment}

Poaching is a situation where school administrators enticed teachers already working in neighbouring schools to leave their places of work and move to work in the poaching administrator's school. The study sought to determine whether or not schools employed this tactic in recruitment. This was tested by giving respondents a statement to the effect 
that the schools employed this method, and the respondents were asked to fill the questionnaire based on the questions which were presented to them. The outcomes of this investigation are expressed in the following Table 4.7.

Table 4.7: The Use of Poaching as a Method of Recruitment

\begin{tabular}{|l|c|c|}
\hline Statement & Frequency & Percentage $(\mathbf{n}=\mathbf{1 1 2})$ \\
\hline Strongly disagree & 47 & 42 \\
\hline Disagree & 45 & 40 \\
\hline Undecided & 12 & 11 \\
\hline Agree & 6 & 5 \\
\hline Strongly agree & 2 & 2 \\
\hline
\end{tabular}

Poaching is a situation where school administrators enticed teachers already working in neighbouring schools to leave their places of work and move to work in the poaching administrator's school. The study sought to determine whether or not schools employed this tactic in recruitment. This was tested by giving respondents a statement to the effect that the schools employed this method, and the participants were guided to express their degree of disagreement or concurrence with it.

Table 4.7 clearly shows that most of the participants did not agree on poaching as a method of recruitment used by private secondary schools to employ teachers. According to the table, $42 \%$ of respondents strongly disagreed with the statement while a further $40 \%$ disagreed, giving a total of $82 \%$ of the respondents in disagreement with the statement. At the same time, $11 \%$ were not sure of the position and therefore remained undecided. Only $5 \%$ of respondents agreed with the statement while $2 \%$ strongly agreed with it. It is therefore clear that poaching is not one of the methods that managers of secondary schools use for recruiting new teachers.

\subsection{Enhancement of Job Performance through Fair Recruitment and Selection}

The study sought to establish whether the recruitment methods employed by the secondary schools studied enhanced employee job performance or not. This was studied through a statement to the effect that fair recruitment and selection process enhance better performance on the job. The respondents were asked to fill the questionnaire based on the questions which were presented to them. The findings of the investigation are portrayed in the following Table 4.8 .

Table 4.8: Enhancement of Job Performance through Fair Recruitment and Selection

\begin{tabular}{|l|c|c|}
\hline Statement & Frequency & Percentage (n =112) \\
\hline Strongly disagree & 1 & 1 \\
\hline Disagree & 0 & 0 \\
\hline Undecided & 1 & 1 \\
\hline Agree & 10 & 9 \\
\hline Strongly agree & 100 & 89 \\
\hline
\end{tabular}


From Table 4.8, it is noted that almost all the respondents agreed that fair recruitment and selection process enhanced job performance. This is because a whopping $89 \%$ of respondents strongly agreed with the statement while a further $9 \%$ agreed with it. This left only $2 \%$ of respondents, $1 \%$ of who was undecided while the remaining $1 \%$ strongly disagreed. It is therefore clear that a fair recruitment and selection strategy enhances the job performance of employees - the teachers in this case.

\subsection{The Use of Newspapers and Internet as Advertisement Methods}

The study sought to determine the recruitment methods employed by the studied schools to publicize the presence of vacancies in the institutions. Particularly, the study was interested in whether the schools used methods like newspaper advertisements, the internet, and such like methods. To achieve this, respondents were stated to the effect that this method was used as a method of publicity. The respondents were asked to fill the questionnaire based on the questions which were presented to them. Results of their views are expressed in the following Table 4.9.

Table 4.9: The Use of Newspapers and Internet for Publicity

\begin{tabular}{|l|c|c|}
\hline Statement & Frequency & Percentage (n =112) \\
\hline Strongly disagree & 0 & 0 \\
\hline Disagree & 1 & 1 \\
\hline Undecided & 0 & 0 \\
\hline Agree & 34 & 30 \\
\hline Strongly agree & 77 & 69 \\
\hline
\end{tabular}

From Table 4.9, it is apparent that almost all participants concurred that the schools employed these kinds of advertisements to recruit teachers. This is because $69 \%$ of the respondents strongly agreed with the statement while a further $30 \%$ agreed with it. This left only $1 \%$ of respondents who disagreed with the statement. It is therefore clear that all administrators in the schools studied used newspaper advertisements and the internet to inform the public about vacancies in their schools. Applicants could then visit the schools for fair recruitment, probably through interviews to select the most suitable teachers for the school.

\subsubsection{Absorption of Internship Employees and Employee Adoption}

The research sought to establish whether the schools studied absorbed instructors initially working as interns, into their service and how this affected the absorbed teachers' adaption to the school environment. To understand this position, a statement to the effect that employees recruited through this method adapted well to the school environment was given to the respondent and based on the questions which were presented to them.

The following Table 4.10 demonstrates the outcome. 
Table 4.10: Absorption of Employees on Internship and Their Adaption

\begin{tabular}{|l|c|c|}
\hline Statement & Frequency & Percentage (n =112) \\
\hline Strongly disagree & 0 & 0 \\
\hline Disagree & 1 & 1 \\
\hline Undecided & 8 & 7 \\
\hline Agree & 11 & 10 \\
\hline Strongly agree & 92 & 82 \\
\hline
\end{tabular}

From Table 4.10, it is clear that the majority of respondents agreed with the statement. This implies that the schools not only absorbed teachers on an internship as part of their staff but that the teachers employed through this method adapted faster to the school environment. From Table 4.10 , it is observed that $82 \%$ strongly agreed with this position while a further $10 \%$ agreed with it. Only $1 \%$ of respondents disagreed while $7 \%$ were undecided. It is therefore clear that employees absorbed from internships adapt faster and better with the school environment, a situation that would lead to better job performance and eventually the good performance of students in the school.

\section{Findings}

The study found that all private secondary schools studied practiced good human resource practices like advertisement of teacher vacancies whenever vacancies arose, establishment of teacher training and development programs, establishment of teacher reward system as well as teacher orientation before allocation of duties.

\section{Conclusion}

From the findings of the study, it is clear that private secondary schools consider the teacher recruitment process to be one of the very important human resource management processes. They, therefore, go a long way in ensuring that the process is as smooth as possible through advertising any vacancies that arise through newspapers, the internet, and other methods that would ensure quality work is done. Specifically, the schools do not entice teachers from neighbouring schools to join other schools unless the teachers respond to the advertisement and go for interviews. The recruitment methods adopted by the studied schools are generally considered as being fair. Fair recruitment, together with the orientation of new teachers and absorption of interns as teachers, tend to increase teacher performance and hence student performance. In other words, good human resource practices encourage teachers to perform their duties well, which also leads to good performance by students and hence the schools. It is also observed that aspects that give rise to teacher motivation eventually lead to better student performance in their examinations, which eventually leads to better school performance. Opportunities for teacher development as well as recognition of teachers for exemplary performance are other aspects that improve teacher performance which leads to better student performance. It is therefore important for organizational managers to develop 
proper human resource practices that enhance teacher motivation, which motivates teachers to improve their efforts. Ultimately, this contributes enhanced student performance and thus the performance of the school as a whole.

\subsection{Recommendations}

- Private secondary schools should ensure that they conduct open recruitment of teachers to fill any available vacancies. Preferably, recruitment through advertisement was found to be the most suitable as all applicants get a similar chance of interview.

- When a vacancy for a teacher arises, school management should consider giving such chances to teachers who are already serving as interns in the school as the priority. This is because teachers on internship were found to be more effective since they do not need any more time for orientation or to adjust to the environment as they are already part of the team. They, therefore, perform better, thereby helping improve the overall student performance and hence the performance of the school as a whole.

\section{Conflict of Interest Statement}

I Nderitu Eunice Wangui declare that I don't have any conflict of interest on this publication.

\section{About the Authors}

Nderitu Eunice Wangui is a Certified Human Resource Management Practitioner, holder of Bachelor of Business Management in Human Resource Management Option and currently finalizing Masters of Arts in Public Policy and Administration in Human Resource Management Specialization and this is her first academic research publication. She participated in data collection of this academic research paper with the help of supervisor Dr. Felistus Makhamara.

\section{References}

Anyango, E., Okibo. B. W. and Muya, J. (2018). Effects of recruitment and selection criteria on Organizational performance at Kisii University, Kenya. International Journal of Social Sciences and Information Technology. Vol IV Issue X.

Armstrong, M. (2014). Armstrong's Handbook of Human Resource Management Practice. (13th Ed.). London, UK: Kogan Page Limited. Armstrong, M., (2006). A Handbook of Human Resource Practice (10th edition). London \& Philadelphia, Kogan Page Ltd.

Branine, M. (2008). Graduate recruitment and selection in the UK. Career Development International, 13(6), 497-513. Budhwar, 2007

Ekwoaba, J. O., Ikeije, U. U. and Ufoma, N. (2015). The impact of recruitment and selection criteria on organizational performance. Global Journal of Human Resource 
Management Vol.3, No.2, pp.22-33. European Centre for Research Training and Development UK

Fahy, J. and Smithee, A. (1999). Strategic Marketing and the Resource Based View of the Firm. Journal of the Academy of Marketing Science Review, Vol. 1999, 10.

Foa, E. B., \& Foa, U. G. (2012). Resource theory of social exchange. In Handbook of social resource theory (pp. 15-32). Springer New York.

Gamage, A. S. (2014). Recruitment and selection practices in manufacturing SMEs in Japan: An analysis of the link with business performance. Ruhuna Journal of Management and Finance, 1(1), 37-52.

Kanyemba, M., Iwu, C. G. and Allen-Ile, C. O. K (2015). Impact of recruitment and selection on organizational productivity. Evidence from staff of a university in South Africa. Corporate Ownership \& Control / Volume 12, Issue 2.

Keshav, P. (2013). Internal Sources and Methods of Recruitment. Academy of Management Journal, 38, 635-672.

Makhamara, F. H., Waiganjo, E. W. and Kwasira, J. (2016). Influence of Strategic Recruitment and Selection on Employee Performance in the Health Sector in Kenya. The Strategic Journal of Business and Change Management. Vol. 3, Iss. 3 (21), pp 347-361.

Munjuri, M. (2011). The Effects of Human Resources Management Practices in Enhancing Employee Performance in Catholic Institutions of Higher Learning in Kenya. Unpublished MBA Project (School of Business - University of Nairobi, Kenya). 
Author(s) will retain the copyright of their published articles agreeing that a Creative Commons Attribution 4.0 International License (CC BY 4.0) terms will be applied to their work. Under the terms of this license, no permission is required from the author(s) or publisher for members of the community to copy, distribute, transmit or adapt the article content, providing a proper, prominent and unambiguous attribution to the authors in a manner that makes clear that the materials are being reused under permission of a Creative Commons License. Views, opinions and conclusions expressed in this research article are views, opinions and conclusions of the author(s). Open Access Publishing Group and European Journal of Education Studies shall not be responsible or answerable for any loss, damage or liability caused in relation to/arising out of conflicts of interest, copyright violations and inappropriate or inaccurate use of any kind content related or integrated into the research work. All the published works are meeting the Open Access Publishing requirements and can be freely accessed, shared, modified, distributed and used in educational, commercial and non-commercial purposes under a Creative Commons Attribution 4.0 International License (CC BY 4.0). 